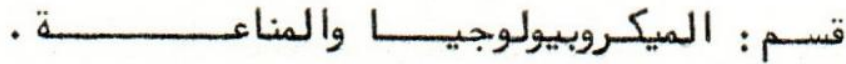

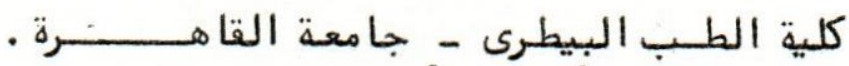

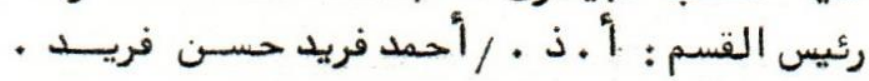

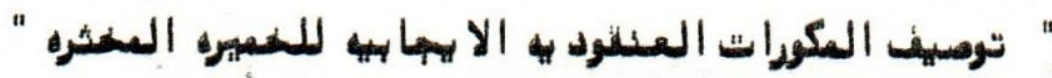
العـرولة منهالات التهاب الغرع فه العامز والافئسام

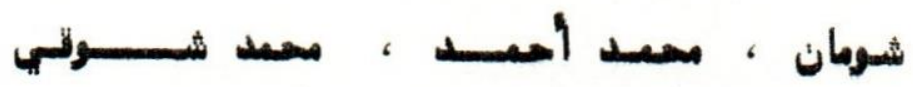

للكشف عن حالات التهاب الضرع تحت الحاده في الماعــــز

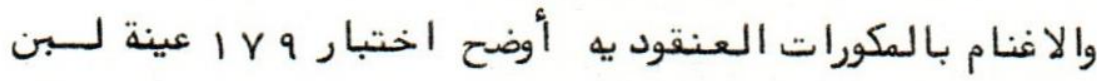

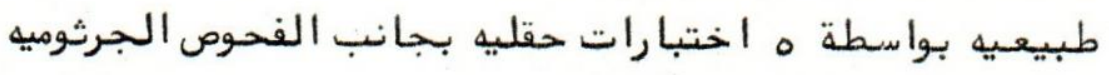

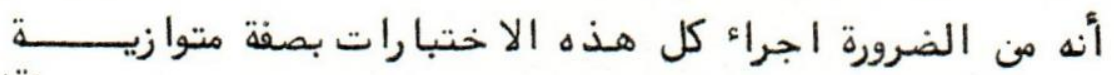

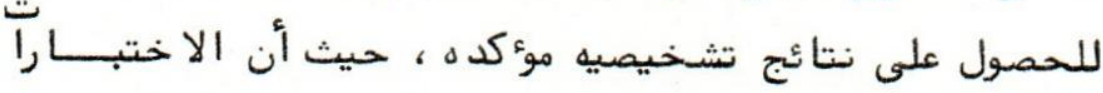
الحقليه لا تكفي للتثخيص في حالة لبن الماعز والاغنام. كما أثبت فحص 1 م عينه لبن مصاب بالتهاب الضرع أن الماعــز

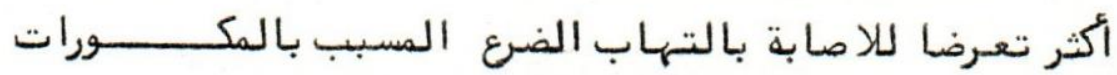

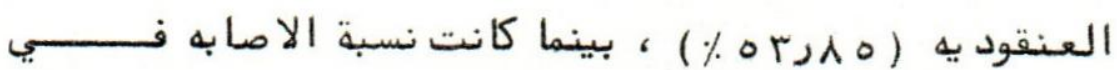

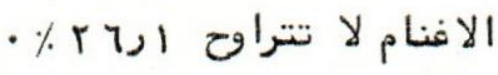

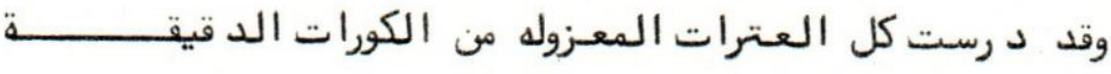

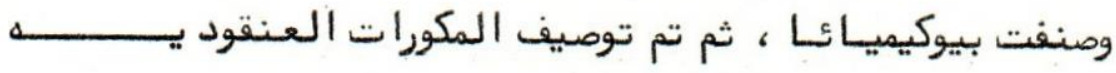

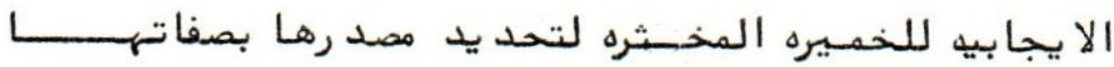

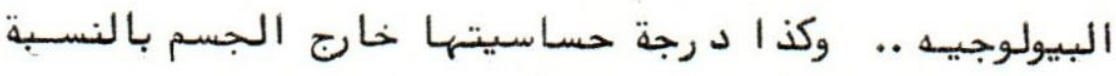

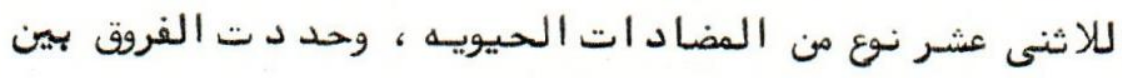

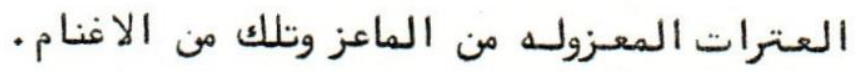


Dept. of Microbiology and Immuninology, Faculty of Vet. Med., Cairo University, Head of Dept. Prof. Dr. A. Farid.

\title{
CHARACTERIZATION OF COAGULASE-POSITIVE STAPH. AUREUS IN GOATS AND SHEEP MASTITIS
}

(With 5 Tables)

\author{
By \\ M.T. SHOUMAN, M. ISMAIL and S.SH. REZK* \\ (Received at 13/2/1983)
}

\begin{abstract}
SUMMARY
Examination of 179 normal milk samples from she-goats and ewes with 5 field tests as well as bacteriological procedures, showed that both methods should be applied in parallel for the proper diagnosis of the subclinical mastitis in both species.

Bacteriological examination of mastitic milk samples from she-goats (39) showed that the acute staphylococcal mastitis was the most prominant type (53.85\%), from which $23.08 \%$ samples showed mixed infection. On contrary, in ewes the acute staphyloccocal mastitis (26.1\%) came in the second level after chronic streptococcal infection.

Characterization of the recovered coagulase-positive strains either from goat origin ( 23 isolates) and 8 strains of sheep origin showed that all of them coagulated rabbit plasma, none coagulated horse plasma and showed variable incidences to cattle, sheep and human plasmas. Most of them were alpha-haemolysin producers (60 - 62\%) and all of them were non-fibrinolytic, which indicated that such isolates were of animal origin. Moreover, according to their susceptibility to chemotherapeutic agents in-vitro, the goat strains were highly sensitive to tetracycline (91.39\%), erythromycin (826\%) and cephalothin (78.3\%), while the sheep strains were affected by chloramphenicol $(87.5 \%)$ and erythromycin $(75.00 \%)$.
\end{abstract}

\section{INTRODUCTION}

In Egypt, FARAG and OOF (1966), EL-GHOOL et al. (1968), EL-RIHIAWY (1969), OOF (1970) and ABDEL-KARIM et al. (1978) recorded the isolation of Staphylococci from normal and mastitic milk samples from different breeds of sheep and goats in variable incidences. Moreover, EL. -SHERRY and FARIS (1974) and BAKEER (1979) applied experimental Staphylococcal mastitis in sheep and goats and concluded that this type was characterized by more destruction of glandular tissue and its replacement with fibrous tissue.

The aim of this work is to record the frequency of Staphylococcal infection in normal and mastitic milk samples from goat and sheep in Behira Province. Elsewhere, the identification of the isolated micrococci, characterization of coagulase positive Staph. aureus isolates and determination their sensitivity to 12 chemotherapeutic agents in vitro were performed.

* Provencial Diagnostic \& Research Lab., Damanhour.

Assiut Vet. Med. J. Vol. 12, No. 23, 1984. 


\section{M.T. SHOUMAN, et al.}

\section{MATERIAL and METHODS}

A total of 260 individual milk samples were collected from 67 she-goats (46 healthy and 21 mastitic ones) and 167 ewes (40 healthy and 27 mastitic) where 179 samples were normal and 81 mastitic-milk samples. All percautions were taken for their collection.

All collected samples from apparently healthy animals were subjected to the following field tests; California mastitis, Whiteside, Bromocresol-purple, Chlorine and Hotis-tests as well as the bacteriological examination.

The 81 mastitic milk samples were examined bacteriologically only, where they were incubated for $24 \mathrm{hrs}$ at $37^{\circ} \mathrm{C}$ as enrichment, then recultivated on 5\% sheep-blood, MacConkey and nutrient-agar plates as routine media in addition to 2 selective differential media as mannitol salt - and Edward's blood-agar plates, then incubated for 48 hrs at $37^{\circ} \mathrm{C}$.

The colonies of Gram-positive, catalase-positive cocci were purified and subjected for further identification of Microccoccaeae (BAIRD-PARKER, 1963; WILSON and MILES, 1975). Furtherly, characterization of coagulase-positive Staph. aureus was performed by applying slide and tube coagulases tests on 5 types of plasma (Rabbit, Sheep, Cattle, Horse and Human plasmas), determination of types of haemolysins on sheep, rabbit, human and horse blood agar plastes, lecithinase activity and other tests recommended by FRANKETL et al. (1970). Moreover, the sensitivity of 31 coagulase-positive Staph. aureus isolates from goat origin and 8 strains from sheep source was tested against 12 types of chemotherapeutic agents (oxoid) using BLAIR et al. (1970) scheme and interpertation.

\section{RESULTS}

Periliminary examination of the 92 normal milk samples from healthy goats with the field tests revealed 13 positive cases (14.13\%), while their bacteriological examination showed 75 positive samples (81.52\%) with the isolation of 133 isolates from which 79 isolates belonged to micrococci. Only 4 cases of positive field tests revealed the recovery of coagulase positive Staph. aureus, where the remained 9 positive field test samples showed 5 with the isolation of saprophytic micrococci either alone or mixed with other pathogens (Table 1). In other instance all mastitic samples were bacteriologically positive, where coagulase-positive Staph. aureus infection either alone or mixed constituted 53.87\% of all samples (Table 2). According to the cauitive agents, 12 samples revealed Staph. aureus in pure form, 5 samples showed mixed infection with streptococci, 3 samples in association with corynebacterium and one sample mixed with $\underline{E}$. coli. The type of organisms associated with coagulase-positive Staph. aureus and their incidences are indicated in table (3). The severity of infection varied which showed decrease in milk profuction and milk appeared grossly normal (subclinical cases) to the acute suppurative form with severe pain and enlargement of the udder or the gangerenous form.

Examination of 87 normal milk samples from ewes showed 13 samples were positive to field tests, while 72 were bacteriologically positive. Coagulase-positive Staph. aureaus was isolated from one milk sample negative to field test, while 5 saprophytic micrococci were recovered from samples positive to field test (Table $1 \& 2$ ). Bacteriological examination of mastitic milk samples from ewes (42) showed that all of them were positive from which 11 samples revealed the isolation of coagulase positive Staph. aureus (26.19\%) and 15 samples with other micrococci (Table 3). Accordingly it was noticed that staphylococcal mastitis in ewes occurred in comparatively lower incidence than in she-goats, and the organism was isolated in pure form (Table 3). 


\section{STAPH. AUREUS IN GOATS AND SHEEP MASTITIS}

Bacteriological and biochemical identification of the 190 micrococcal isolates showed that most of them, 117 isolates (61.05\%), were coagulase-negative Staph. epidermidis; 38 (20\%) coagulase-positive Staph. aureus and 35 isolates of coagulase-negative micrococci belonged to 5 biotypes. The 117 Staph. epidermidis were differentiated into the following 4 biotypes; 75 isolates of biotype V, 23 biotype I, 10 biotype III and 9 isolates of biotype II.

Characterization of 31 strains of coagulase-positive Staph. aureus (23 from goat and 8 sheep strains) by applying the tests to determine their origin (animal or human origins). The results showed that they were of animal origin as all of them were non-fibrinolytic, $60 \%$ of them were alpha -haemolysin producers, and $100 \%$ of the strains coagulate rabbit plasma within 24 hours (Table 4). On other aspect, 8 strains from goats and 3 sheep ones coagulated human plasma, while no strain of both sources could coagulate horse plasma. The other characters of coagulase-positive Staph. aureus were described briefly in table (4).

Concrning the effect of the different chemotherapeutic agents on goat an sheep strains, it was found that the Staph. aureus of goat sources were highly susceptible to tetracycline (91.30\%), erythromycin $(\overline{82.60 \%)}$ and cephalothin (78.36\%). On other side, the sheep strains (8) were highly sensitive to only 2 types; chloramphenicol (87.5\%) and erythromycin (75.0\%), and were of less susceptibility to tetracycline and cephalothin. Moreover, the sheep strains were resistant to gentamycin in contrast to goat strains. Ampicillin, pencillin and strptomycin showed siight effect, while Staph. aureus strains of both species resisted completely the effect of colistin sulphate and nalidixic acid (Table 5).

\section{DISCUSSION}

Concerning the 13 normal milk samples from goats positive to field tests, only 4 samples revealed coagulase-positive Staph. aureus, while the organism could not be recovered from the 12 positive ewes milk samples (Table 1). On other aspect, 2 strains were isolated from two normal milk samples negative to field test from both species (Table 2). Although a variety of fieid tests had been applied for the diagnosis of subclinical mastitis in both species, the proper interpertation of the result was completed by the application of bacteriological examination as some normal milk samples negative to fieid tests yielded a potential pathogens as Staph. aureus (Table 2). This conclusion can be confirmed by SMITH and ROGUINSKY (1977) who suggested that some field tests must be interpreted cautiosly when applied to goat.

The results showed that staphylococcal mastitis was the most frequent type in she-goats representing 53.85\% of examined milk samples (Table 3). This agrees with EL-GHOOL et al. (1968), EL-REIHIAWY (1969), OOF (1970) and SMITH and ROGUINSKY (1977) who reported that haemolytic Staph. aureus was teh most important pathogen amongst goat mastitis. In ewes, staphylococcal mastitis occurred in lower incidence (26.19\%) and the organism was isolated in pure form as stated by ABD-EL-KARIM et al. (1978). Also ROSSES (1972) recorded 18 cases of staphylococcal mastitis from 358 milk samples from ewes.

Characterization of the isolated Staph. aureus (23 isolates of goat origin and 8 of sheep source) showed that some differences in their characters and some similarities, as $87.5 \%$ of sheep strain clotted cattle plasma in comparison to $47.9 \%$ of goat strains, sheep strains had more lecithinase activities than the goat one, but nearly $60 \%$ of both of them were alpha-haemolysin producers. It can be concluded, that such strains are of animal origin but differed from that of bovine strains. Also these findings requires more investigation according to the suggestion of DIEVERSE and OEDING (1976) that the majority of Staph. aureus strains of human, animal and poultry origin fiffered in certain physiological properties and differentiated accordingly to different biotypes.

Assiut Vet. Med. J. Vol. 12, No. 23, 1984. 


\section{M.T. SHOUMAN, et al.}

Such suggestion was proved by the results of the sensitivity to chemotherapeutic agents, as the 23 goat strains were highly susceptible to tetracycline, erythromycin and cephalothin, while sheep strains were highly affected by chloramphenicol and erythromycin as EL-RIHIAWY (1969) and ABD-EL-KARIM et al. (1978). Also GODA et al. (1980), using BLAIR et al. (1970) interpettation, found that $\overline{41}$ strains of coagulase positive Staph. aureus from different hosts were sensitive to cephalothin (87.9\%), erythromycion (73.2\%) and tetracyclin (65.9\%).

\section{REFERENCES}

Abdel-Karim, A.M.; Mahmoud, S. and Ghoneim, H. (1978): Studies on Staphylococcus aureus and Escherichia coli as causative organisms of mastitis in Egyptian dairy animal. J. Egypt. Vet. Med. Assos., 38/3, 9-15.

Baird-Parker, A.C. (1963): A classification of micrococci and staphylococci based on physiological and biochemical tests. J. gen. Microbiol., 30, 409-417.

Bakeer, A.M. (1979): Histopathological studies on experimental mastitis in goats. M.V.Sc. Thesis, Pathology, Cairo Univ.

Blair, J.E.; Lennete, E.H. and Truand, J.P. (1970): Manual of Clinical Microbiology. Amer. Soc. for Microbiol., Bethesda.

Devriese, L.A. and Oeding, P. (1976): Characteristics of Staphylococcus aureus strains isolated from different animal species. Res. Vet. Sci., 21, 284-291.

El-Ghool, A.M.; Nada, S.; Khalil, M.Y.; Fakhry, A.; Mahanna, M.A. and Emam, H. (1968): A study on mastitis in Marino ewes in Abis farm. J. Egypt. Vet. Med. Assoc., 28, 1-5.

El-Rihiawy, M.S. (1969): The bacterial flora found in cases of mastitis in sheep and goats with reference to the in vitro action of antibiotics on the isolated organisms. M.D.Vet. Thesis, Bacteriology, Assiut University.

El-Sherry, M. and Faris, M.O. (1974): Comparative histopathological study experimental yeast and bacterial mastitis in Awasi sheep. J. Egypt. Vet. Med. Assoc., 34, 47-61.

Farrag, H. and Dof, F. (1966): Etiology of goats' mastitis in U.A.R. Indian Vet. J., 43, 771-777.

Frankel, S.; Reitman, S. and Sonnenwirth, A.C. (1970): Gradwohl's Clinical Laboratory Methods and Diagnosis. 7th Ed., C.V. Mosby Co., Saint Leuis, US.

Goda, F.F.; Shouman. M.T.; Wassef, N.A.; Sawah, H. and Saad, Zeinab (1981): Cogaulae-positive staphylococci as surface contaminant on carcasses and hands of human attendants and their host adapted varieties. Vet. Med. J., Cairo Univ., 29, (In press).

Oof, F.M. (1970): Studies on mastitis in Egyptian dairy animals. M.D.Vet. Thesis, Vet. Hygiene, Cairo University.

Rosses, Th. (1972): Subclinical and chronic clinical staphylococcal mastitis of sheep and goats in Attica district. Deltiontes Kllenikes Kteniatriks Etaireas, 23, 188-199.

Smith, M.C. and Roguinsky, M. (1977): Mastitis and other diseases of the goats' milk. J.A.V.M.A., 171, 1241-1248.

Wilson, C.S. and Miles, A.A. (1975): Topley and Wilson's Principles of Bacteriology, Virology and Immunity. 6th Ed., Edward Arnol Ltd., London. 


\section{STAPH. AUREUS IN GOATS AND SHEEP MASTITIS}

Table (1)

Corelation between the positive field test normal milk samples from she-goats and ewes and isolation of micrococci

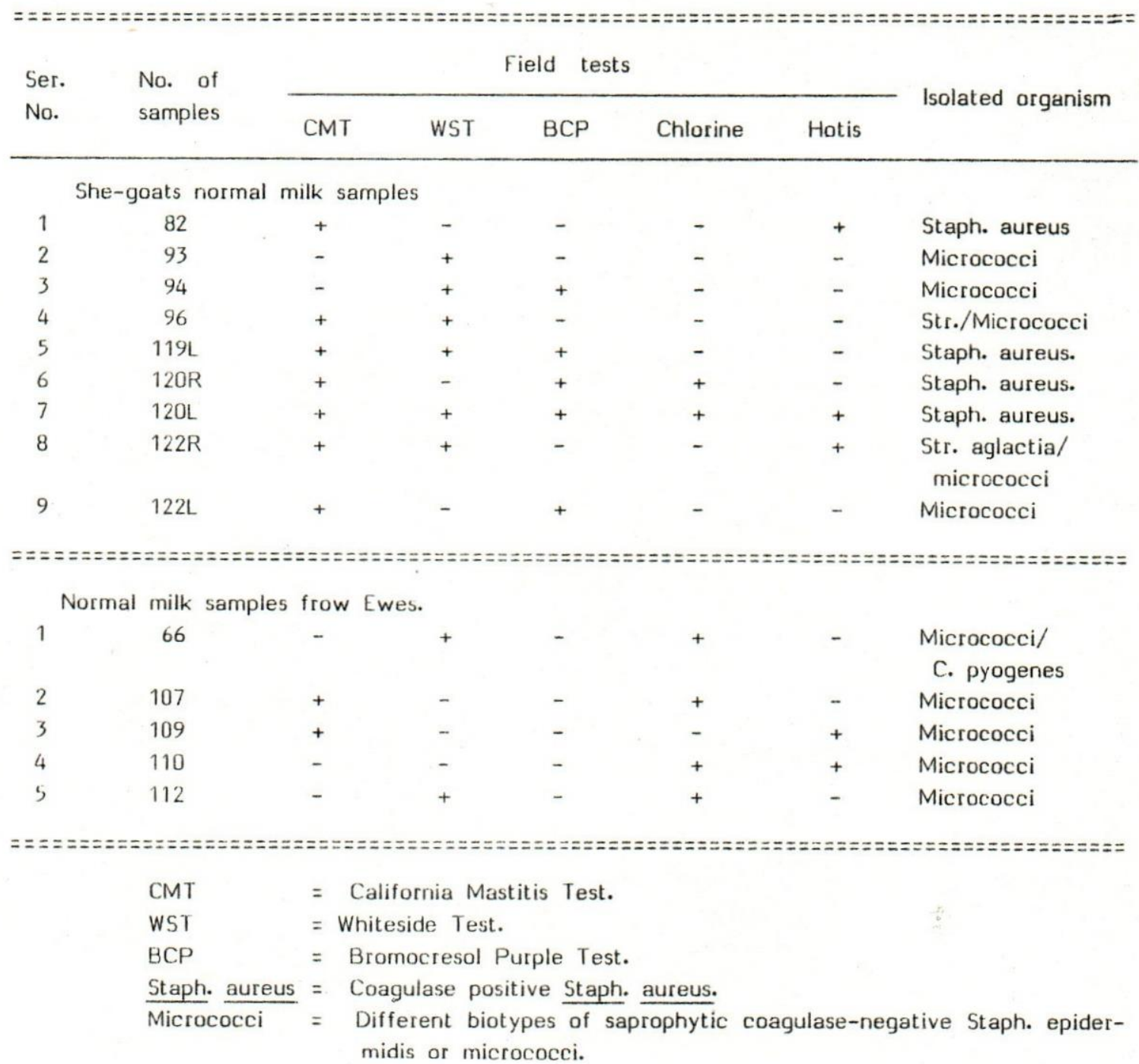




\section{M.T. SHOUMAN, et al.}

Table (2)

Number, incidence, species and distribution of staphylococci

in all examined milk samples

\begin{tabular}{|c|c|c|c|c|c|c|c|c|c|c|}
\hline \multirow{3}{*}{$\begin{array}{l}\text { Bacterial } \\
\text { species }\end{array}$} & \multicolumn{2}{|c|}{ Isolates } & \multicolumn{8}{|c|}{$\begin{array}{l}\text { Source \& type of samples } \\
\text { She-goats }\end{array}$} \\
\hline & \multirow[t]{2}{*}{ No. } & \multirow[t]{2}{*}{$\%$} & Normal & $(92)$ & Mast & is $(39)$ & No & mal (87) & Mast & ic (42) \\
\hline & & & No. & $\%$ & No. & $\%$ & No. & $\%$ & No. & $\%$ \\
\hline $\begin{array}{l}\text { Staph. aureus } \\
\text { Staph. epidermidis }\end{array}$ & 38 & 20.0 & 5 & 5.43 & 21 & 53.85 & 1 & 1.15 & 11 & 26.19 \\
\hline $\begin{array}{l}\text { Staph. epidermi } \\
\text { ( } 4 \text { biotypes) }\end{array}$ & 117 & 61.58 & 60 & 65.22 & 4 & 10.26 & 45 & 51.72 & 8 & 19.04 \\
\hline $\begin{array}{l}\text { Micrococci } \\
\text { (5 biotypes) }\end{array}$ & 35 & 18.42 & 14 & 15.22 & 5 & 12.82 & 9 & 10.34 & 7 & 16.67 \\
\hline & 190 & & 79 & & 30 & & 55 & & 26 & \\
\hline
\end{tabular}

Table (3)

The frequency of staphylocococcal or mixed infection in mastitic milk from both species

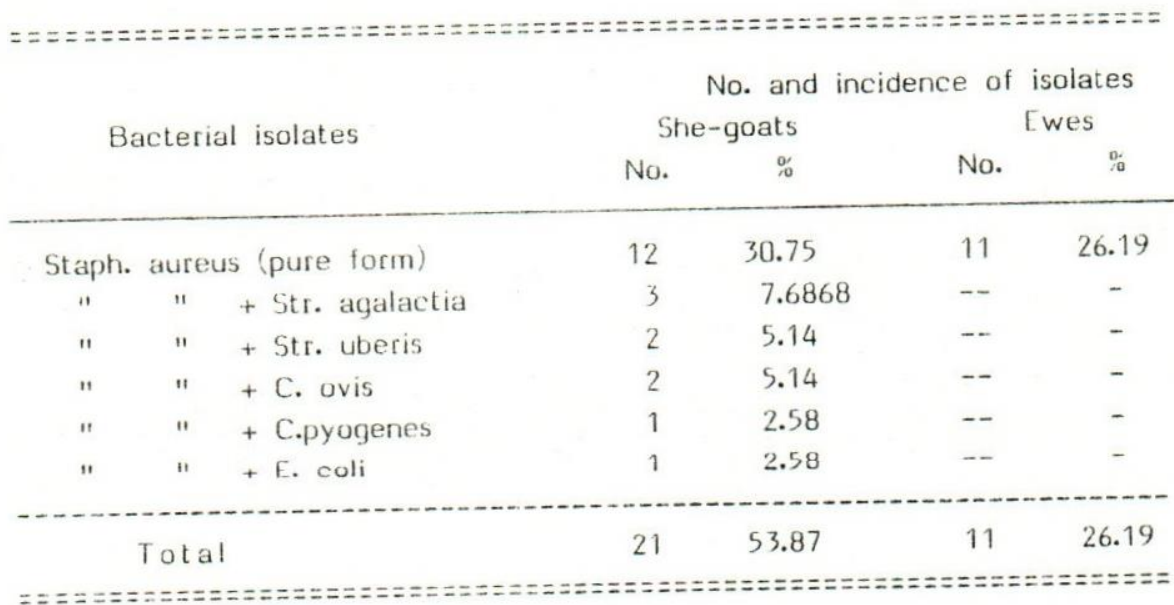

Assiut Vet. Med. J. Vol. 12, No. 23, 1984. 


\section{STAPH. AUREUS IN GOATS AND SHEEP MASTITIS}

Table (4)

Specific characters of Staph. aureus isolated from milk samples

\begin{tabular}{|c|c|c|c|c|}
\hline \multirow{2}{*}{$\begin{array}{l}\text { Specific } \\
\text { reactions }\end{array}$} & \multicolumn{2}{|c|}{ Goat strains (23) } & \multicolumn{2}{|c|}{ Sheep strains (8) } \\
\hline & No. & $\%$ & No. & $\%$ \\
\hline \multicolumn{5}{|l|}{ Growth on } \\
\hline - Mercuric chloride & 21 & 91.3 & 7 & 87.5 \\
\hline - Crystal violet & 21 & 91.3 & 7 & 87.5 \\
\hline Violet colonies & \multicolumn{2}{|c|}{ (17) } & \multicolumn{2}{|c|}{ (4) } \\
\hline \multicolumn{5}{|l|}{ Coagulation of } \\
\hline - Rabbit plasma & 23 & 100.0 & 8 & 100.0 \\
\hline - Human plasma & $\underline{8}$ & 34.8 & 3 & 37.5 \\
\hline - Sheep plasma & $1 \overline{3}$ & 56.5 & 5 & 52.5 \\
\hline - Cattle plasma & 11 & 47.8 & 7 & 87.5 \\
\hline - Horse plasma & -- & - & - & -- \\
\hline \multicolumn{5}{|l|}{ Haemolysin types } \\
\hline - Alpha & 14 & 60.9 & 5 & 62.5 \\
\hline - Beta & 3 & 13.0 & 1 & 12.5 \\
\hline - Gamma & 6 & 26.1 & 2 & 25.0 \\
\hline Lecithinase activ. & 9 & 39.1 & 4 & 50.0 \\
\hline Mannitol Ferm. & 19 & 82.6 & 6 & 75.0 \\
\hline Gelatine Liquef. & 3 & 13.0 & 1 & 12.5 \\
\hline Urea Hydrolysis & 12 & 52.2 & 5 & 62.5 \\
\hline
\end{tabular}

()$=$ number of strains examined. 
106

M.T. SHOUMAN, et al.

Table (5)

Effect of different chemotherapeutic agents on coagulase-positive Staph. aureus from goat and sheep origin

\begin{tabular}{|c|c|c|c|c|c|}
\hline \multirow[b]{2}{*}{ Agents } & \multirow{2}{*}{$\begin{array}{l}\text { Zone of } \\
\text { Inhibit. } \\
\text { in } \mathrm{mm} \S\end{array}$} & \multicolumn{2}{|c|}{ Goat strains (23) } & \multicolumn{2}{|c|}{ Ewes Str. ( 8 ) } \\
\hline & & No. & $\%$ & No. & $\%$ \\
\hline Tetracycline & 14 & 21 & 99.3 & 5 & 62.5 \\
\hline Erythromycin & 13 & 19 & 82.6 & 6 & 75.0 \\
\hline Cephalothin & 14 & 18 & 78.4 & 5 & 62.5 \\
\hline Chloramphenicol & 12 & 16 & 69.6 & 7 & 87.5 \\
\hline Gentarnycin & 12 & 14 & 60.9 & 3 & 37.5 \\
\hline Ampicillin & 20 & 9 & 39.1 & 1 & 12.5 \\
\hline Pencillin G & 20 & 9 & 39.1 & 2 & 25.0 \\
\hline Streptomycin & 11 & 8 & 34.8 & 2 & 25.0 \\
\hline Neomycin & 12 & 1 & 4.3 & - & - \\
\hline Colistin sulphate & 8 & - & - & - & - \\
\hline Nalidixic acid & 13 & - & - & - & - \\
\hline Sulphatride & 12 & - & - & 1 & 12.5 \\
\hline
\end{tabular}

$\S$ According to Blair et al. (1970).

( ) Number of strains examined. 